\title{
Aristotelian framing: logos, ethos, pathos and the use of evidence in policy frames
}

Iris Stucki and Fritz Sager

\begin{abstract}
In this research note, we propose to complement the analytical toolbox for framing analyses with the categories of Aristotelian rhetoric. As our case, we analyse the function of the use of evidence in frame building in the context of Swiss direct-democratic campaigns preceding votes on smoking bans. Based on rhetoric, a frame can be considered to contain three interrelated elements: (1) political arguments (logos), (2) cultural symbols (ethos), and (3) emotional appeal (pathos). By comparing evidence-based arguments with arguments that do not refer to evidence, the research note illustrates that backing arguments (logos) by evidence increases their trustworthiness (ethos) but not their emotional appeal (pathos). We consider the Aristotelian categories a fruitful tool to enlarge existing framing research with regard to the use of evidence.
\end{abstract}

Keywords: Logos; Ethos; Pathos; Policy framing; Aristotle; Use of evidence; Policy arguments

\section{Introduction}

Lasswell (1951) coined the term intelligent democracy, a democracy in which free access to scientific evidence provides for an informed public discourse. Such an evidence-based discourse is especially relevant in direct-democratic campaigns where political actors aim to convince citizens to oppose or support a policy through arguments (Stucki et al. 2018; Sager et al. 2017b; Sager 2017). To this end, political actors frame their arguments, that is, "they select some aspects of a perceived reality and make them more salient in a communicating text" (Entman 1993: 52). Supporting evidence may be integrated into the frame for the purpose of making the arguments convincing (Wolf and Van Dooren 2017). The question of the function of evidence in a frame has, with some exceptions (Wolf and Van Dooren 2017; Druckman and Bolsen 2011), mainly been neglected so far. This research note addresses this gap by proposing to study the use of evidence in frames from a rhetorical perspective.

The growing interest in deliberation and persuasion in the mass media has led to a "recent wave of interest in the rhetorical tradition among political theorists" (Garsten 2011: 159). The tradition of rhetoric makes it possible to widen the focus of political processes "in particular the importance of ethos, virtue, trust, feelings and emotions" (Gottweis 2007: 248). In the following, we present the Aristotelian rhetoric categories of logos, ethos, and pathos as a systematic way to study political frames and illustrate our framework with the empirical case of direct-democratic campaigns in Switzerland. 
Switzerland is a particularly appropriate arena in which to situate the study, because Swiss citizens have the final say in most of the important decisions of national politics (Sager and Zollinger 2011; Sager et al. 2017a), and they base their voting choices pre- dominantly on arguments in the media provided by political actors during the campaign (Bonfadelli and Friemel 2012: 173; Kriesi 2012: 234). Campaigns can be perceived as "a series of communication events conducted by political actors in order to influence voters" (Kriesi 2012: 11). The communication in the media is of particular importance in forming opinions (Bonfadelli and Friemel 2012). The media represents the arena through which different actors can participate and present arguments (Peters et al. 2008). The media arena thus provides a platform where political actors can speak to the voters, similar to the environment of a one-to-many audience imagined by Aristotle. With this, direct-democratic campaigns facilitate the translation of the Aristotelian context to the present time, which makes them an ideal environment to study the important lessons that ethos, pathos, and logos can teach us today.

Based upon a comparison of arguments in Swiss direct-democratic campaigns on smoking bans, the illustrative study makes two contributions to existing research on the use of evidence in political communication. First, we provide for a comparative framework that allows analysing the function of evidence in a frame. Second, we show that while reference to evidence (logos) increases the trustworthiness of what is said (ethos), such reference is not able to increase the emotional mobilization of the audience (pathos).

The next section introduces the theoretical background on the rhetorical perspective on policy frames and the structure of logos, ethos, and pathos in frames. Then, information is provided on the empirical method and the findings of the analysis. The article concludes in discussing further possibilities to apply the rhetorical tradition on concepts from political science.

\section{A rhetorical perspective on policy frames}

Policy frames are commonly perceived as problem-setting stories (Schön and Rein 1995: 27, 30) that explain "what is wrong and what needs to be fixed" (Schön and Rein 1995: 28). Empirical research on frame building includes a broad range of policy fields and conceptions, and the body of research is growing. Studies on frame building focus on the elements that can be found in frames (see, e.g. Baumgartner et al. 2008; Jerit 2008; Levin 2005; Marx Ferree et al. 2002; McAuliffe Straus 2011; D’Angelo and Kuypers 2010; Gruszczyn- ski and Michaels 2012), while studies on framing effects analyse the reactions to variations in wording of a frame (Tersky and Kahneman 2000; Druckman and Bolsen 2011). A lot of typological and systematic research can be found in the existing framing research. In the cognitive linguistics literature on the one hand, known for observing the language structure to understand political behaviour, Lakoff (2002) is able to show in a convincing manner how (un)conscious metaphors shape moral visions. Studies in the realm of the argumentative turn (Fischer and Gottweis 2012; Schmidt 2012), on the other hand, that understand policy ideas, frames, or narratives as social 
constructs in the form of an interpretative framework to give meaning to physical and social realities provide tools to analyse how relations of powers are structured and reproduced (see also Hajer 2002).

The present study incorporates a rhetorical perspective into those studies of policy frames with a focus on the function of evidence. Advocacy plays a key role in the adoption of particular policies, and understanding the rhetorical dynamics of this advocacy will enable scholars to better understand the policymaking process. Rhetoric as linguistic art is the essence of framing (Gruszczynski and Michaels 2012: 360). This especially holds true for direct-democratic campaigns because with frames, political actors aim to persuade the audience that a certain policy will probably be better than another (Kuypers 2009: 6). To study the function of evidence in frames, we propose an analytical framework based on the Aristotelian rhetoric. Concretely, our concept of a frame consists of three interrelated elements: (1) logos, (2) ethos, and (3) pathos. Those analytical categories can be found in existing research on frames in the form of political arguments (e.g. Entman 1993; Kohring and Matthes 2002) for logos, cultural symbols (e.g. Chong and Druckman 2007; Gamson and Modigliani 1989; Snow and Benford 1988) for ethos and emotional appeal (e.g. And- sager 2000; Jerit 2009; Yanow 2000) for pathos. Our framework allows for a comparative analysis regarding evidence in frames by comparing frames where evidence is used with frames without evidence.

The elements logos, ethos, and pathos are interconnected in reality: trust and emotion are not just supplements or corruptions of public reasoning but integral parts of it (Haidt 2012; Garsten 2011: 170). In political psychology, dual-process models propose that individuals form their opinion through two processes, an automatic versus a controlled process (Lieberman 2007). It is assumed that automatic processes give a fast emotional basis for decision making (Haidt 2007) which can be supported or corrected by reflecting on the information (Kahneman and Frederick 2005, 267-268; Haidt 2007, 316). While it is not yet clear whether the emotional system is the primary driver of understanding (Marcus 2000) or even tightly bound to cognition (Lodge and Tabor 2005), passion has an important role in politics: emotion forms an integral part of information processing (Redlawsk 2006); that is, rational cognitive processing requires emotional processing (McDermott 2004, 693). It can be shown that knowing without feeling leads to distorted decision-making processes (Damasio 2007, p. 78).

Thus, all political arguments have an emotional appeal and all emotional appeal has a referral to arguments, although these are not always backed up by evidence or other sources of information. However, for the present analysis, we deconstruct the frames and analyse the elements separately to be able to see how the elements interact. 
Logos, ethos, and pathos and how they interact

Rhetoric, according to Aristotle (1926), relies on the interplay of the three elements of ethos, pathos, and logos: persuasion takes place when the speech is delivered in such a manner as to render the orator worthy of trust (ethos) (Rhet. I.2.4), when the audience is roused to emotions by his speech (pathos) (Rhet. 1.2.5) and when truth is established by

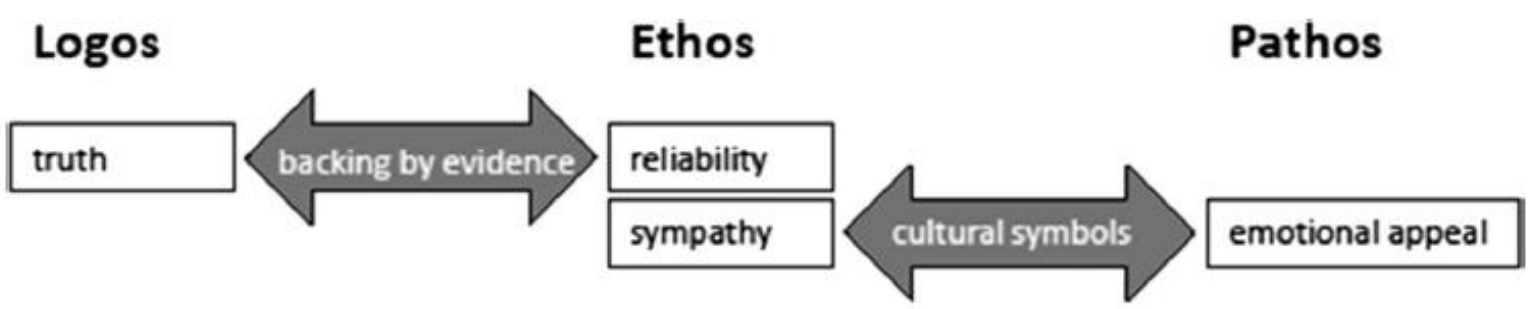

Fig. 1 Hypothesis: interaction between logos, ethos, and pathos

the speech (logos) (Rhet. I.2.6). Thus, speech (and not the speaker) is emphasized (Rhet. I.2.4). Logos describes the argument of the speech, the rational proof of the issue (Knape 2000: 34). Ethos has two variants in rhetoric: (1) the speaker's reliability in suggesting that he will tell the truth and (2) the quality of the speaker in winning the sympathy of the hearers (Wisse 1989: 7). ${ }^{1}$ Thus, ethos depends not only on professional competence made transparent by means of a compelling argumentation (Knape 2000: 43-44) but also on demonstrating ideological credentials which lead to identification with a particular cultural milieu (Atkins and Finlayson 2014: 1-2, 11; Finlayson 2012: 795-760). That is, ethos determines the trustworthiness in formulating an argument that is both logically and culturally convincing. Finally, pathos describes the affective dimension of rhetoric (Arceneaux 2012: 282), that is, the emotional mobilization of the audience (Fischer 2009: 275).

Evidence "has to be introduced in some way by the participants as part of their framing the policy problem" (Wesselink et al. 2014: 341). The next paragraph clarifies how evidence is integrated in the frame. Figure 1 serves as an overview.

According to recent argumentation theory (Dunn 2012; Wohlrapp 2009), an argument in a directdemocratic campaign consists of three fundamental components: (1) suitable policy information, (2) a claim to vote for or against the issue, and (3) a warrant, the justification for the claim which relates the policy information to the claim. The warrant can have different modes of reasoning (Dunn 2012: 344345). Two common modes of reasoning in direct-democratic campaigns are cause (observed effects of policy interventions) and ethics (moral principles or ethical norms) (Stucki 2016). Optionally, an

\footnotetext{
${ }^{1}$ Wisse (1989, p. 317) specifies that the "ethos of sympathy" is based on Aristotle's version of ethos, while the "rational" ethos can be traced back to Cicero.
} 
argument can also include a backing, a justification for the warrant (Cranmer et al. 2011). The backing has the function of certifying the assumptions expressed in the warrant (Brockriede and Ehninger 1960). By providing reliability for what is said, evidence as backing contributes to strengthening the argument and to enhancing trust in the argument by making the argument more convincing (Mercier and Sperber 2011: 61). As shown above, reliability is part of the trustworthiness of the speaker, the ethos part of the frame. Thus, backing the argument by evidence connects logos, the political argument, to ethos, the speaker's reliability.

As for the rhetorical category of pathos, according to Wisse (1989: 7, 241), only the sympathy part of ethos is related to emotional appeal, because only if the speaker wins the sympathy of the hearers is an emotion, positive or negative, aroused in the audience. The sympathy part of ethos is related to the demonstration of a shared cultural identity, made visible by cultural symbols (Atkins and Finlayson 2014: 1). Cultural symbols are the essence of meaningful communication with others (Elder and Cobb 1983: 56) and allow individuals to experience a sense of collective participation. Thereby, they arouse intense emotions in individuals (Turner and Stets 2005: 292-293, see also Wolf and Van Dooren

2017). Atkins and Finlayson (2014: 6) show, for example, how quotations supporting an argument intensify pathos by providing identification with a cultural and political community. Hence, quotations as cultural symbols, or rather the authorities referred to, are able to lead to an increase in emotional appeal because they enhance sympathy. At the same time, quotations act as "authoritative factual evidence" (Atkins and Finlayson 2014: 6) by establishing truth and increasing the reliability of what is said. That is, quotations are a special kind of evidence that may, due to their reference to authorities, at the same time enhance sympathy and reliability. Other cultural symbols may include metaphors or proverbs (Wolf and Van Dooren 2017: 455).

It can be assumed that, in general, cultural symbols primarily enhance sympathy because they first and foremost refer to the cultural identity. It can further be assumed that, in contrast to the use of cultural symbols in a frame, backing by evidence is related to reliability but not to sympathy because evidence is not part of the cultural identity. Thus, the core hypothesis of this illustrative study reads as follows: backing an argument (logos) by evidence increases its trustworthiness (ethos) but not its emotional appeal (pathos).

\section{Data and method}

To examine the hypothesis, this research note uses data from a research project on the use of evidence in direct-democratic campaigns (Stucki 2016). As this is a research note and not a full research paper, the presented analysis is to be considered illustrational rather than a robust and definitive test of the hypothesis. The case covers 16 campaigns conducted in the German part of Switzerland on whether to ban smoking in public places. The research material consists of the daily newspapers with the highest circulation at the national and cantonal level which appeared during the campaigns and the respective 
governmental booklets $(\mathrm{N}=578)$ (cf. Stucki 2016). This research material represents the main source for opinion formation for Swiss voters (Bonfadelli and Friemel 2012: 176). The unit of analysis consists of statements of participants in the discourse (cf. Stucki 2016 reference for further information about coding procedure and reliability). We retrieved each statement from the material $(\mathrm{N}=2947)$ and then noted where evidence was used as backing. Based on Shulock's definition (1999: 233), backing by evidence occurred if evidence was referred to in the argument. Evidence was broadly defined: it included all references both to scientific evidence in general ("Newest data shows...", $\mathrm{N}=74$ ) and to specific scientific studies ("A study by the University of Zurich shows...", $N=110$ ). Specific scientific studies included policy evaluations assessing the value of a political measure along with scientific studies without explicit connection to a state measure (e.g. basic medical studies, opinion data from health surveys or monitoring studies). Prior analyses show that the major topics in the debate concerned health and economic impact (both arguments based on causal war- rants) and personal freedom (ethics) (Stucki 2016). In total, 1534 statements covered those topics, and 146 were backed by evidence. To move from the individual statements to the larger campaign, we formed clusters (see Stucki 2016 for procedure). Three clusters refer to personal freedom:

- Personal freedom of smokers ( $n=416$; example: to force guests not to smoke is humiliating paternalism) [C1]

- Personal freedom of non-smokers ( $n=267$; example: the right to be forced to passively smoke takes precedence over the right to smoke anywhere) [C2]

- Moderate claim $(n=44$; example: with unattended smoking rooms, smokers can continue smoking) [C3]

Three clusters refer to health impact:

- Harm of passive smoking ( $n=309$; example: smoking bans lead to health improvements such as fewer heart attacks, less cardiovascular diseases and less hospital admissions) [C4]

- Harm of passive smoking for employees ( $n=110$; example: employees are especially affected; they need health protection at their workplace) [C5]

- Inconvenience ( $\mathrm{n}=17$; example: passive smoke is more an inconvenience than a severe hazard) [C6]

Three clusters refer to economic impact

- Negative economic impact ( $n=184$; example: the existence of restaurants is threatened) [C7]

- No negative economic impact ( $n=174$; loss of sales does not take place; in fact, the reverse occurred) [C8]

- Investments ( $\mathrm{n}=13$; example: investments for smoking rooms are made useless) [C9] 
On the basis of this dataset, we were able to compare statements in the same cluster, with and without the use of evidence.

\section{Findings}

Our interest is with the question of how the use of evidence in arguments (logos) inter- acts with the rhetoric categories of ethos and pathos in policy frames. Of course, as shown above, all arguments include logos, ethos, and pathos, because they are interconnected. What our analysis does is put a lens on the argument. Presenting our findings, we first focus on how the category of ethos links to the use of evidence in backing an argument (logos), before we perform the same analysis for pathos.

\section{Ethos}

Backing increases the trustworthiness of the speaker by creating more credibility, that is, the quality of convincing logically, for the argument. This can be shown by taking arguments based on causal warrants such as when referring to the health impacts of smoking bans. In the following statement, the government uses a study to back its argument that there is a relation between exposure to second-hand smoke and mortality ${ }^{2}$ :

In its report on the protection against second-hand smoke from 10 March 2006, the Federal Council quantifies the number of persons that die yearly due to passive smoking to amount to several hundred (Governmental booklet Thurgau 2009) [C4]

The increase in credibility can be shown when the argument is compared with the statement of a politician, in which he does not use evidence:

Hundreds of people die each year as a result of passive smoking. (Appenzeller Zeitung 3.11.07) [C4]

Unrelated to evidence, this statement cannot be distinguished from pure allegation. The situation is somewhat different for frames that are based on ethics referring to personal freedom. Here, the studies used to back the argument are not policy evaluation studies but opinion surveys and monitoring studies. In such frames, the function of evidence lies in raising personal opinions towards the opinions of a majority, that is, adding objectivity, which again increases the trustworthiness of the speaker. The message of the following two statements, both from the committees for smoking bans, is the same:

The term "liberal" is strained badly by the innkeepers' association (...) the initiative (...) does not only annoy guests but also employees. (Basler Zeitung, 13. 10. 2011) [C2]

Studies have shown that three-quarters of employees are harassed by cigarette smoke. (Governmental booklet, Basle-City 2011) [C2]

\footnotetext{
${ }^{2}$ All quotations are translated by the authors.
} 
Here, the second statement, in adding the reference to "studies", adds objectivity (and credibility). The example shows that greater credibility can also be achieved by just adding a general reference. However, citing a specific reference makes the statement even more trustworthy. In the following statement, a journalist refers to a specific study when pointing to the health impact of passive smoking:

In 1986 a report from the US Department of Health and Human Services, based on the current evidence, confirmed for the first time [that] passive smoking increases the risk of lung cancer. (journalist, Tagesanzeiger, 21. 9. 2012) [C4]

For comparison, the following statement, where a citizen uses general evidence when pointing to the same health impact, correlates with a slight decrease in credibility:

Today we know from numerous studies that passive smoking damages our health, causes diseases and kills. Anyone who is forced to inhale smoke from others risks falling victim to lung cancer (...). (Neue Zürcher Zeitung, 14. 9.2012) [C4]

Thus, the level of the backing has an impact on the increase in ethos. It does not, however, lead to a decrease in emotional appeal, on the contrary. The second statement has a higher emotional appeal to fear than the first. We will analyse the reasons for this in more detail in the next section. For evidence in connection with ethos, in summary, we find two functions: credibility can be raised in causal arguments while objectivity can be raised in normative arguments; this increase is highest for specific references. We now turn to pathos, the emotional appeal of a frame.

\section{Pathos}

Three types of emotions are most often included in studies that measure emotions: (1) anger (indicators: hatred, contempt, bitterness, resentment), (2) anxiety (indicators: anxiety, worry, fear), and (3) enthusiasm (indicators: enthusiastic, hopeful, proud) (Brader 2006: 151; Druckman and McDermott 2008: 301; Marcus et al. 2006; Steenbergen et al. 2003: 160). Appeal to anger results from arguments focusing on the violation of social norms, appeal to anxiety results from arguments pointing to the suffering of individuals or to severe consequences (Gross and D'Ambrosio 2004: 2; Kühne 2014), and benefit is associated with enthusiasm (Cobb 2005: 231-232). We now contrast appeals to the three emotions of enthusiasm (benefit), anxiety (severe consequences), and anger (violation of social norms), with and without reference to evidence, starting with enthusiasm. The following statement made by the committee for smoking bans argues the benefit of the policy measure, pointing to the profit for restaurant owners, without using evidence:

Restaurants profit from healthy staff, new guests, [and] lower cleaning costs and they even save costs on ventilation. (Governmental booklet, St. Gallen 2009) [C8]

The emotional appeal to enthusiasm remains the same in a similar message, pointing to the benefit from an increase in turnover, where a citizen uses evidence to back his argument: 
It can be read in the report of the government of New York City that ten months after the introduction of the law concerning smoke-free workplaces the tax revenues of restaurants and bars increased by 8.7 per cent - thus, enforcement of non-smoking has substantially increased turnover. (Schaffhauser Nachrichten, 27. 4. 2005) [C8]

The absence of a difference in emotional appeal with and without evidence also applies to the appeal to fear. A statement from a restaurant owner, pointing to the severe consequence of threat to existence, aims to evoke fear without using evidence:

[Smoking bans] lead to a loss of sales, employees will have to be laid off, a lot of restaurants will even have to close, especially small restaurants (...). (Thurgauer Tag- blatt, 8.5.2009) [C7] There is no apparent difference in emotional appeal when the statement refers to evidence, such as a stakeholder saying:

According to a study (...) the decline in sales amounts to 6 per cent in the cantons of Tessin, Geneva and Grisons. For small restaurants it amounts to a full 12 per cent. (Neue Nidwaldner Zeitung, 18.9.2008) [C7]

The only increase is in credibility, resulting from the statement "according to a study" as was shown in the section on ethos. An example of an appeal to anger is the following statement of a politician pointing to the violation of personal freedom of smokers, which he backs by evidence:

The individual freedom of the citizens will now (...) be erased completely. (...) Thereby nothing will change. Worldwide studies prove that (...) governments taking drastic measures will not lead to the desired decline of nicotine consumption. (Tagesanzeiger, 1.5.2008) [C1]

The statement of a citizen also aiming to evoke anger by pointing to the violation of personal freedom has a slightly higher emotional appeal, even though it does not use evidence:

How much more state protection do they want? (...) [We've had] enough of this (...) holy war, led by the fundamentalist non-smokers, because they regard themselves as a special minority group worthy of protection. (Basler Zeitung, 21. 11. 2011) [C1]

The increase of emotional appeal seems to be caused by the expressions "holy war" and "fundamentalist non-smokers". It appears that, instead of evidence, the cultural symbols found in "special words or phrases that express public values" (Andsager 2000: 580; see also Olausson 2009: 431) manipulated effectively by political actors are able to increase emotional appeal.

\section{Discussion}

Employing a framing concept informed by Aristotelian rhetoric, we have been able to analyse the function of evidence in a frame: The analysis indicates that evidence can increase the trustworthiness of 
its speaker when explicitly used to back an argument but it does not increase the emotional appeal of the frame.

There are several limitations to this study. We did not take into account the persuasion that lies outside of the speech itself, what Aristotle called inartistic forms of persuasion (Aristotle, 15, 1375a-15). Inartistic persuasion takes place for example, when someone's position may persuade a voter not because of what the person says, but because that person is member of a party. The testing of the hypothesis remains illustrative, because we focused on the emotional appeal and did not test the actual framing effects or the true emotional impact. The emotions that the political actors are primarily trying to evoke in the voters do not have to be the same as the actual emotional impact (Brader 2006: 149150). To move the results from assertions to facts, we would need to empirically test the hypotheses. With the help of an experiment, we would be able to examine how evidence impacts both credibility and emotional appeal. With an experiment, we could also gain empirical evidence on the impact of the gradation of evidence and the cultural symbols. Druckman and Bolsen (2011) experimentally tested the framing effects of the use of evidence. The results show that the use of evidence does not alter voters' attitudes but strengthens their attitudinal sup- port (and their behavioural intention) in increasing the certainty of their attitudes. This result indicates that the findings of our study concerning credibility point to the assumed direction.

In bringing back ethos and pathos, the integration of rhetoric has the potential to extend the notion of political concepts and to enrich the study of political theories. Evidence-based policy making (EBPM), for example, starts from the premise that a political practice can be improved by integrating evidence into the political decision-making process. This should ensure that political decisions are "well informed" and made on the basis of "what works" (Nutley et al. 2010: 133). Direct-democratic campaigns challenge this rationalist view of the use of evidence and call for an interpretative view (Schlaufer et al. 2018). In making their decision, voters need to take into account ethical and moral concerns. Against this background, EBPM can be understood as "practical rationality" rather than "instrumental rationality" (Sanderson 2006: 115), where evidence is used as "rational" legitimization of the appropriate solutions to the problem rather than as epistemic foundation showing the best impact in an objective way (Shulock 1999). But what is the function of evidence in such an understanding of EBPM? Here again, a recourse to Aristotle may be beneficial. Aristotle distinguishes three approaches to knowledge: episteme, techne, and phronesis. Episteme concerns knowledge achieved with the aid of scientific methods, techne is practical-technical knowledge associated with art and craft, and phronesis reflects the values and ethics of knowledge (Flyvbjerg 2001). The practical rationality of EBPM lies very close to the rhetorical concept of phronesis. As an "intellectual virtue of practical reason" (Self 1979: 133), phronesis encompasses the ability to make a choice when the outcome is uncertain and normative considerations are entangled with facts (Majdik and Keith 2011: 376). 
Existing research that connects phronesis and EBPM can be found in Flyvbjerg's concept of the social sciences a "phronetic approach" (Schram et al. 2013), that is, a science that is context based and that produces knowledge with practical implications in an ongoing social dialogue. Building on this research, further studies in the area of political com- munication considered phronesis in a broadened notion as discursive knowledge where conflicting values come together (Mukhtarov and Gerlak 2014) or as specific form of argumentation, one that answers questions of desirability, next to practicability (techne) and evidence (episteme) (Tenbensel 2006). Based on this, a similar analysis to the one pre- sented here could investigate the function of evidence in EBPM. Starting from the premise that an optimal policy debate includes answers to techne, episteme, and phronesis (Tenbensel 2006), we could compare arguments with and without reference to evidence and analyse how this evidence (episteme) is related to techne and phronesis, that is, values and practicability. Regarding the relation between episteme and phronesis, for example, our studies on smoking bans indicate that arguments on values (phronesis) have a wider public acceptance if they are connected to evidence which is publicly accepted and not contested by the opposition (Stucki 2017). It would be interesting to deepen those relations or to analyse other political concepts and the function of evidence with the help of the rhetorical tradition in such a comparative way.

\section{Conclusion}

All reasoning is argumentative and the aim of reasoning is to form arguments intended to persuade and to convince others (Mercier and Sperber 2011: 58; Haidt 2012). Thus, in direct-democratic campaigns, evidence is used politically; that is, proponents and opponents select findings that support their arguments to enrich the political discourse with evidence-based presentations of different perspectives (Boswell 2009: 73, 89; Shulock 1999: 229). The ultimate function of the political use of evidence is to raise the credibility of one's positions and to discredit the positions of the opposition (Boswell 2009; Shulock 1999). This study contributes to further clarifying the role of evidence in directdemocratic campaigns, in providing an analytical framework that allows comparing arguments with and without evidence.

By means of rhetoric, the concept of the political use can be corroborated in this regard and broadened. On the one hand, we show that there is an increase in credibility but also how this increase comes about. On the other hand, the results indicate that the emotional appeal is not part of the political use of evidence. Thus, for political actors to foster greater participation and more vibrant democratic debates, cultural symbols in frames should best be combined with evidence: such frames might have an even greater mobilizing function because, due to the increase in credibility, their emotional appeal might be reinforced.

Acknowledgements Funding was provided by the Swiss National Science Foundation (Grant No. CRSII1_141893/1). 


\section{References}

Andsager, J. (2000). How interest groups attempt to shape public opinion with competing news frames. Journalism and Mass Communication Quarterly, 77(3), 577-592.

Arceneaux, K. (2012). Cognitive biases and the strength of political arguments. American Journal of Political Science, 56(2), 271-285.

Aristotle. (1926). The "art” of rhetoric (Vol. XXII) (J. H. Freese, transl.). Cambridge, MA: Harvard University Press.

Atkins, J., \& Finlayson, A. (2014). “As Shakespeare so memorably said...”: Quotation, rhetoric, and the performance of politics. Political Studies, 62(1), 1-18.

Baumgartner, F., De Boef, S., \& Boydstun, A. (2008). The decline of the death penalty and the discovery of innocence. New York: Cambridge University Press.

Bonfadelli, H., \& Friemel, T. (2012). Learning and knowledge in political campaigns. In H. Kriesi (Ed.), Political communication in direct democratic campaigns. Enlightening or manipulating? Challenges to democracy in the 21 st century series (pp. 168-187). New York: Palgrave Macmillan.

Boswell, C. (2009). The political uses of expert knowledge. Immigration policy and social research. Cambridge: Cambridge University Press.

Brader, T. (2006). Campaigning for hearts and minds. How emotional appeals in political ads work. Chicago: The University of Chicago Press.

Brockriede, W., \& Ehninger, D. (1960). Toulmin on argument: An interpretation and application. Quarterly Journal of Speech, 1006, 45-53.

Chong, D., \& Druckman, J. (2007). Framing theory. Annual Review of Political Science, 10, 103-126.

Cobb, M. (2005). Framing effects on public opinion about nanotechnology. Science Communication, 27(2), 221-239.

Cranmer, M., Petit, R., \& Sager, F. (2011). Die argumentative Logik der Tabakmandate des Alten Bern: Eine historische Policy-Analyse. Swiss Political Science Review, 17(4), 432-446.

D’Angelo, P., \& Kuypers, J. A. (2010). Doing news framing analysis. New York: Routledge.

Damasio, A. R. (2007). Descartes' Irrtum. Fühlen, Denken und das menschliche Gehirn. Berlin: List.

Druckman, J., \& Bolsen, T. (2011). How scientific evidence links attitudes to behaviors. In D. A. Dana (Ed.), The nanotechnology challenge (pp. 85-102). New York: Cambridge University Press.

Druckman, J., \& McDermott, R. (2008). Emotion and the framing of risky choice. Political Behavior, 30(3), 297-321. 
Dunn, W. (2012). Public policy analysis. Hoboken, NJ: Pearson.

Elder, C., \& Cobb, R. (1983). The political uses of symbols. New York: Longman.

Entman, R. (1993). Framing: Toward clarification of a fractured paradigm. Journal of Communication, 43(4), 51-58.

Finlayson, A. (2012). Rhetoric and the political theory of ideologies. Political Studies, 60(4), 751-767.

Fischer, F. (2009). Democracy and expertise: Reorienting policy inquiry. Oxford: Oxford University Press.

Fischer, F., \& Gottweis, H. (2012). The argumentative turn revisited. In F. Fischer \& H. Gottweis (Eds.), The argumentative turn revisited: Public policy as communicative practice (pp. 1-30). Durham: Duke University Press.

Flyvbjerg, B. (2001). Making social science matter: Why social inquiry fails and how it can succeed again. Cambridge: Cambridge University Press.

Gamson, W., \& Modigliani, A. (1989). Media discourse and public opinion on nuclear power: A constructionist approach. American Journal of Sociology, 95(1), 1-37.

Garsten, B. (2011). The rhetoric revival in political theory. Annual Review of Political Science, 14(1), 159-180.

Gottweis, H. (2007). Rhetoric in policy making: Between logos, ethos, and pathos. In F. Fischer, G. J. Miller, \& M. S. Sidney (Eds.), Handbook of public policy analysis. Theory, politics, and methods (pp. 237-250). Sound Parkway, NW: CRC Press.

Gross, K., \& D’Ambrosio, L. (2004). Framing emotional response. Political Psychology, 25(1), 1-29.

Gruszczynski, M., \& Michaels, S. (2012). The evolution of elite framing following enactment of legislation. Policy Sciences, 45(4), 359-384.

Haidt, J. (2007). The new synthesis in moral psychology. Science, 316(998), 998-1002.

Haidt, J. (2012). The righteous mind. Why good people are divided by politics and religion. England: Penguin.

Hajer, M. A. (2002). Discourse analysis and the study of policy making. European Political Science, $2(1), 61-65$.

Jerit, J. (2008). Issue framing and engagement: Rhetorical strategy in public policy debates. Political Behavior, 30(1), 1-24. 
Jerit, J. (2009). How predictive appeals affect policy opinions. American Journal of Political Science, 53(2), 411-426.

Kahneman, D., \& Frederick, S. (2005). A model of heuristic judgment. In K. J. Holyoak \& R. G. Morrison (Eds.), The Cambridge handbook of thinking and reasoning (pp. 267-293). New York: Cambridge University Press.

Knape, J. (2000). Allgemeine Rhetorik. Stuttgart: Reclam.

Kohring, M., \& Matthes, J. (2002). The face(t)s of biotech in the nineties: How the German press framed modern biotechnology. Public Understanding of Science, 11(2), 143-154.

Kriesi, H. (2012). Political communication: An integrated approach. In H. Kriesi (Ed.), Political communication in direct democratic campaigns. Enlightening or manipulating? (pp. 1-16). New York: Palgrave Macmillan.

Kühne, R. (2014). Political news, emotions, and opinion formation: Toward a model of emotional framing effects. National Center of Competence in Research (NCCR) Democracy Working Paper No. 68.

Kuypers, J. (2009). What is rhetoric? In J. Kuypers (Ed.), Rhetorical criticism. Perspectives in action (pp. 1-28). New York: Lexington Books.

Lakoff, G. (2002). Moral politics. How liberals and conservatives think. Chicago: The University of Chicago Press.

Lasswell, H. D. (1951). The policy orientation. In D. Lerner \& H. D. Lasswell (Eds.), The policy sciences (pp. 3-15). Stanford, CA: Stanford University Press.

Levin, D. (2005). Framing peace policies: The competition for resonant themes. Political Communication, 22(1), 83-108.

Lieberman, M. D. (2007). Social cognitive neuroscience: A review of core processes. Annual Review of Psychology, 58(1), 259-289.

Lodge, M., \& Tabor, C. (2005). Implicit affect for political candidates, parties and issues: An experimental test of the hot cognition hypothesis. Political Psychology, 26(6), 455-482.

Majdik, Z., \& Keith, K. (2011). Expertise as argument: Authority, democracy, and problem-solving. Argumentation, 25(3), 371-384.

Marcus, G. E. (2000). Emotions in politics. Annual Review of Political Science, 3(1), 221-250. 
Marcus, G., MacKuen, M., Wolak, J., \& Keele, L. (2006). The measure and mismeasure of emotion. In D. Redlawsk (Ed.), Feeling politics. Emotion in political information processing (pp. 31-46). New York: Palgrave Macmillan.

Marx Ferree, M., Gamson, W., Gerhards, J., \& Rucht, D. (2002). Shaping abortion discourse. Democracy and the public sphere in Germany and the United States. Cambridge: Cambridge University Press.

McAuliffe Straus, R. (2011). Citizens' use of policy symbols and frames. Policy Sciences, 44(1), 1334.

McDermott, R. (2004). The feeling of rationality: The meaning of neuroscientific advances for political science. Perspectives on Politics, 2(04), 691-706.

Mercier, H., \& Sperber, D. (2011). Why do humans reason? Arguments for an argumentative theory. Behavioral and Brain Sciences, 34(2), 57-111.

Mukhtarov, F., \& Gerlak, A. K. (2014). Epistemic forms of an integrated water resources management: towards knowledge versatility. Policy Sciences, 47(2), 101-120.

Nutley, S., Morton, S., Jung, T., \& Boaz, A. (2010). Evidence and policy in six European countries: Diverse approaches and common challenges. Evidence \& Policy: A Journal of Research, Debate \& Practice, 6, 131-144.

Olausson, U. (2009). Global warming — global responsibility? Media frames of collective action and sci- entific certainty. Public Understanding of Science, 18(4), 421-436.

Peters, H. P., Heinrichs, H., Jung, A., Kallfass, M., \& Petersen, I. (2008). Medialization of science as a prerequisite of its legitimization and political relevance. In D. Cheng, M. Claessens, T. Gascoigne, J. Metcalfe, B. Schiele, \& S. Shi (Eds.), Communicating science in social contexts (pp. 71-92). Dordrecht: Springer.

Redlawsk, D. P. (2006). Feeling politics: New research into emotion and politics. In D. R. Redlawsk (Ed.), Feeling politics. Emotion in political information processing (pp. 1-10). New York: Palgrave Macmillan.

Sager, F. (2017). Evaluation and democracy: Do they fit? In Evaluation and program planning. https:// doi.org/10.1016/j.evalprogplan.2017.08.005.

Sager, F., Ingold, K., \& Balthasar, A. (2017a). Policy-Analyse in der Schweiz. Besonderheiten, Theorien, Beispiele. Zürich: NZZ Verlag.

Sager, F., Widmer, T., \& Balthasar, A. (Eds.). (2017b). Evaluation im politischen System der SchweizEntwicklung, Bedeutung und Wechselwirkungen. Zürich: NZZ Verlag. 
Sager, F., \& Zollinger, C. (2011). The Swiss political system in comparative perspective. In C. Trampusch \& A. March (Eds.), Switzerland in Europe. Continuity and change in the Swiss political economy (pp. 27-42). London: Routledge.

Sanderson, I. (2006). Complexity, "practical rationality" and evidence-based policy making. Policy \& Politics, 34(1), 115-132.

Schlaufer, C., Stucki, I., \& Sager, F. (2018). The political use of evidence and its contribution to democratic discourse. Public Administration Review. https://doi.org/10.1111/puar.12923.

Schmidt, V. A. (2012). Discursive institutionalism. Scope, dynamics, and philosophical underpinnings. In F. Fischer \& H. Gottweis (Eds.), The argumentative turn revisited. Public policy as communicative practice (pp. 85-113). Durham: Duke University Press.

Schön, D., \& Rein, M. (1995). Frame reflection: Toward the resolution if intractable policy controversies. New York: Basic Books.

Schram, S. F., Flyvbjerg, B., \& Landman, T. (2013). Political political science: A phronetic approach. New Political Science, 35(3), 359-372.

Self, L. (1979). Rhetoric and phronesis: The Aristotelian ideal. Philosophy and Rhetoric, 12(2), 130145. Shulock, N. (1999). The paradox of policy analysis: If it is not used, why do we produce so much of it? Journal of Policy Analysis and Management, 18(2), 226-244.

Snow, D., \& Benford, R. (1988). Ideology, frame resonance, and participant mobilization. In B. Klandermans, H. Kriesi, \& S. Tarrow (Eds.), From structure to action: Social movement participation across cultures (pp. 197-217). Greenwich: JAI.

Steenbergen, M., Bächtiger, A., Spörndli, M., \& Steiner, J. (2003). Measuring political deliberation: A dis- course quality index. Comparative European Politics, 1, 21-48.

Stucki, I. (2016). Evidence-based arguments in direct democracy: The case of smoking bans in Switzerland. Evaluation and Program Planning. https://doi.org/10.1016/j.evalprogplan.2016.08.019.

Stucki, I. (2017). Arguing about smoking bans: The role of evidence in the social construction of conflicting policy ideas. Critical Policy Studies, 11(4), 411-432.

Stucki, I., Pleger, L., \& Sager, F. (2018). The making of the informed voter: A split-ballot survey on the use of scientific evidence in direct-democratic campaigns. Swiss Political Science Review. https://doi. org/10.1111/spsr.12290.

Tenbensel, T. (2006). Policy knowledge for policy work. In The work of policy: An international survey (pp.199-216). Latham MC: Lexington Books.

Tersky, A., \& Kahneman, D. (2000). Choices, values, and frames. New York: Cambridge University 
Press. Turner, J., \& Stets, J. (2005). The sociology of emotions. Cambridge: Cambridge University Press.

Wesselink, A., Colebatch, H., \& Pearce, W. (2014). Evidence and policy: Discourses, meanings and practices. Policy Sciences, 47(4), 339-344.

Wisse, J. (1989). Ethos and pathos. Amsterdam: Hakkert.

Wohlrapp, H. (2009). Der Begriff des Arguments. Würzburg: Königshausen and Neumann.

Wolf, E. E. A., \& Van Dooren, W. (2017). How policies become contested: A spiral of imagination and evi- dence in a large infrastructure project. Policy Sciences, 50(3), 449-468.

Yanow, D. (2000). Conducting interpretative policy analysis. Thousand Oaks, CA: Sage. 